\title{
Amorphous state stability of plant vitrification solutions
}

Krystyna Vozovyk ${ }^{1}$,

\author{
Olena Bobrova ${ }^{2 *}$,
}

Anton Prystalov',

Nadiya Shevchenko',

\section{Larisa Kuleshova ${ }^{3}$}

${ }^{1}$ Laboratory of Phytocryobiology,

Institute for Problems

of Cryobiology and Cryomedicine

of the National Academy

of Sciences of Ukraine,

Pereyaslavskaya St. 23,

Kharkiv 61015, Ukraine

${ }^{2}$ Department of Cryobiophysics, Institute for Problems

of Cryobiology and Cryomedicine

of the National Academy

of Sciences of Ukraine,

Pereyaslavskaya St. 23,

Kharkiv 61015, Ukraine

${ }^{3}$ Department of Low

Temperature Preservation,

Institute for Problems

of Cryobiology and Cryomedicine

of the National Academy

of Sciences of Ukraine,

Pereyaslavskaya St. 23,

Kharkiv 61015, Ukraine
Two critical factors for obtaining high viable biological samples after cryopreservation by vitrification method are cryoprotectant glass-forming ability while cooling and the stability of its amorphous state during warming. The present work is devoted to the study of the amorphous state stability of plant vitrification solutions (PVS) by differential scanning calorimetry method. The objects of the study were PVS1 modified, PVS2, PVS3 modified, PVS4 and PVSN. The thermograms of PVSs, frozen in liquid nitrogen, were recorded at a warming rate of $0.5 \mathrm{deg} / \mathrm{min}$. The glass transition temperatures of PVS1, PVS2 and PVS3 were $-109.0^{\circ} \mathrm{C},-115.3^{\circ} \mathrm{C}$, and $-93.9^{\circ} \mathrm{C}$, respectively. Neither exo- nor endothermic peaks have been recorded, indicating no crystallization, at the cooling and the warming stages. PVS4 and PVSN thermograms, besides glass transition $\left(-111.5^{\circ} \mathrm{C}\right.$ and $-110.0^{\circ} \mathrm{C}$, correspondingly), showed crystallization from the amorphous state (devitrification) and ice melting peaks. Crystallization enthalpy of PVSN was 2.8 times higher compared to PVS4. This fact testifies that the crystalline phase was larger in PVSN compared to PVS4. It should be noted that crystallization in PVS4 and PVSN may be related to the low warming rate used during the experiment. At higher warming rates, this crystallization is likely to be avoided. Thus, PVS1, PVS2 and PVS3 have a high glass-forming ability and a stabile amorphous state. The amorphous state stability of PVS4 and PVSN is significantly lower compared to PVS1, PVS2, and PVS3.

Keywords: plant vitrification solutions, glass transition, amorphous state stability, devitrification, ice melting

\footnotetext{
*Corresponding author. Email: helen.bobrova.77@gmail.com
} 


\section{INTRODUCTION}

The deterioration of the environmental quality parameters urges preservation of plant biodiversity (Volis, 2016). Nowadays, development of new plant germplasm cryopreservation methods is very important, since it provides a possibility of long-term survival of the gene pool of valuable species (Pritchard et al., 2014). Vitrification is a convenient cryopreservation method for practical use. It comprises maximum high cooling rates usually achieved by immersion of samples directly into liquid nitrogen, as well as high concentrations of cryoprotectants to prevent intracellular crystallization (Kim et al., 2009; Ruzic et al., 2013). Multicomponent media are often used in order to reduce the cell damage during saturation with vitrification solutions. Such combined cryoprotective media for plant cryopreservation by vitrification are called PVS (plant vitrification solution; Uragami et al., 1989). As a rule, these media have high toxicity to plant explants, therefore the saturation time, the object structure and size, the equilibration temperature, and the PVS concentration should be considered in order to reduce the damaging effect.

The modifications of the available composition of PVS for various plants, as well as the development of new combined solutions (Kim et al., 2009; Vicenja et al., 2010) are currently being continued. Dilution of PVS with water is one of the approaches to avoid its pronounced toxicity to plant explants (Nishizawa et al., 1993). These aqueous solutions could enable saturation of larger objects with cryoprotectant at room temperature for a longer time, thereby providing better penetration of the cryoprotectant into plant cells without viability affection.
Due to the high concentrations of various substances in their composition, PVSs do not crystallize when cooled, and when they reach a certain temperature they are transferred into the solid amorphous state. However, the absence of crystallization at the cooling stage does not exclude its occurrence while heating above the glass transition temperature. Crystal formation at the temperatures above the glass transition as well as the temperature and the intensity of crystallization characterize the stability of the amorphous state (Baudot et al., 1996; Baudot, Boutron, 1998; Baudot et al., 2000). During cryopreservation by vitrification, the achievement of a stable glassy state and the avoidance of ice formation are two critical factors for obtaining high viable biological samples. However, the stability of the amorphous state and the glass-forming ability of a number of concentrated and diluted aqueous PVSs have not yet been clarified. The development of cryogenic technologies is facilitated by biophysical studies capable of monitoring glass stability during cryopreservation (Zámečník et al., 2012).

The purpose of the study was to investigate the glass-forming ability and the amorphous state stability of PVSs, which are promising for plant cryopreservation, using differential scanning calorimetry (DSC).

\section{MATERIALS AND METHODS}

For the preparation of different PVSs, the following cryoprotectants were used: dimethyl sulfoxide (DMSO), ethylene glycol (EG), 1,2-propanediol (1,2-PD), glycerol, and sucrose (Sigma Aldrich, Germany) (Table 1). $100 \%$ and $80 \%$ solutions of PVSs were prepared by diluting

Table 1. Composition of $\mathbf{1 0 0 \%}$ PVSs

\begin{tabular}{cc}
\hline Solution & Composition \\
\hline PVS1 modified & $22 \%$ glycerol $+13 \% 1,2-\mathrm{PD}+13 \% \mathrm{EG}+6 \%$ DMSO $+13.5 \%$ sucrose \\
\hline PVS2 & $30 \%$ glycerol $+15 \%$ EG $+15 \%$ DMSO $+13.5 \%$ sucrose \\
\hline PVS3 modified & $44 \%$ glycerol $+44 \%$ sucrose \\
\hline PVS4 & $35 \%$ glycerol $+20 \%$ EG $+20.5 \%$ sucrose \\
\hline PVSN & $15 \%$ glycerol $+15 \%$ EG $+34 \%$ sucrose \\
\hline
\end{tabular}


cryoprotectants with Murashige and Skoog medium: PVS1 modified, PVS2, PVS3 modified, PVS4, and PVSN.

The phase and glass transitions of PVSs in the temperature range from $-196^{\circ} \mathrm{C}$ to complete media melting were investigated using low-temperature DSC (Zinchenko et al., 2015). Glass transition temperature $\left(T_{g}\right)$ was determined as a midpoint between the onset and endset of the inflectional tangent. Crystallization $(T)$ and melting $\left(T_{m}\right)$ temperatures were determined as an extrapolated onset-temperature (the designed point of intersection of the extrapolated baseline and the inflectional tangent at the beginning of the melting or crystallization peak). The samples were frozen by immersion into liquid nitrogen, with an average cooling rate of 200 degrees/min. The thermograms were recorded during warming with the rate of 0.5 degrees/ $\mathrm{min}$. The weight of all the investigated samples was $1 \mathrm{~g}$.

\section{RESULTS AND DISCUSSION}

DSC-thermograms of PVS1 modified, PVS2, and PVS3 modified (Fig. 1, Table 2) revealed

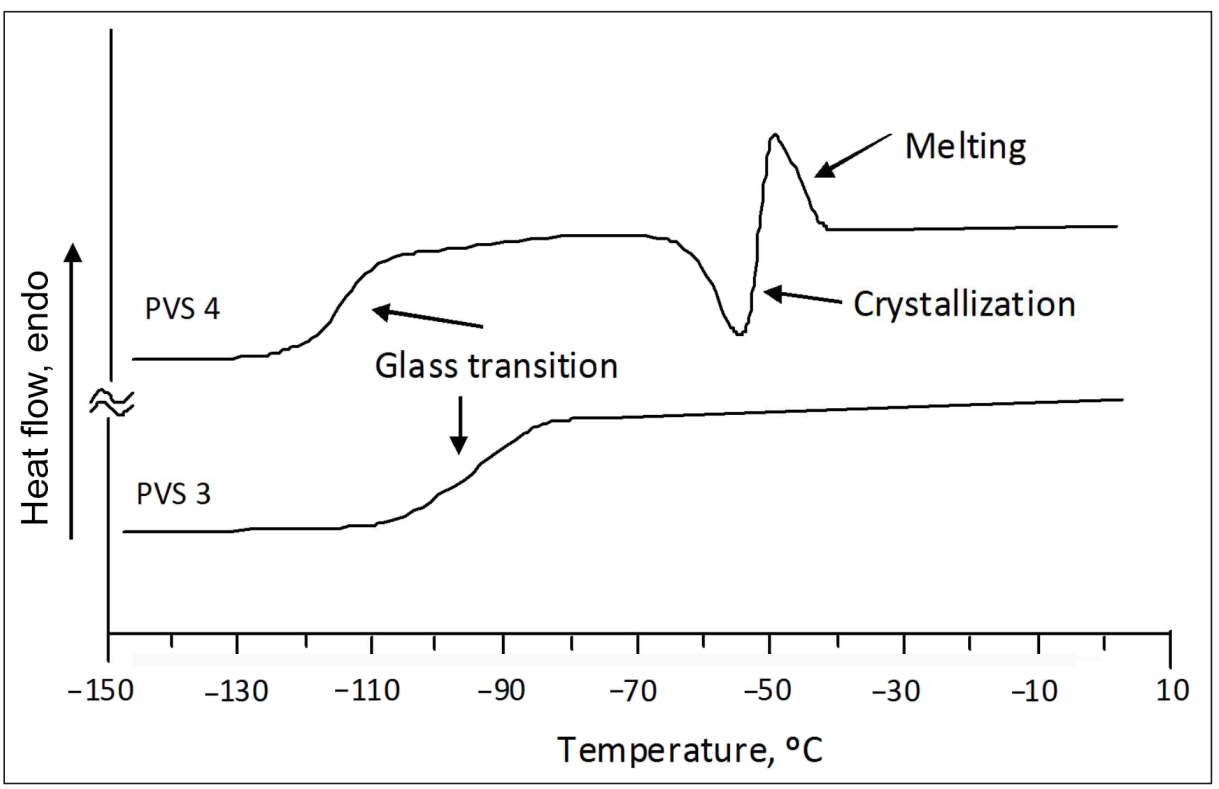

Fig. 1. DSC-thermograms of PVS

Table 2. Temperature of phase and glass transitions crystallization of PVS

\begin{tabular}{c|ccc}
\hline Sample & $T_{g},{ }^{\circ} \mathbf{C}$ & $T_{o}{ }^{\circ} \mathbf{C}$ & $\boldsymbol{T}_{m},{ }^{\circ} \mathbf{C}$ \\
\hline PVS1 modified & $-109.0 \pm 0.5$ & - & - \\
\hline 80\% PVS1 modified & $-116.2 \pm 0.5$ & $-72.0 \pm 0.5$ & $-45.7 \pm 0.5$ \\
\hline PVS2 & $-115.3 \pm 0.5$ & - & - \\
\hline 80\% PVS2 & $-123.0 \pm 0.5$ & $-114.3 \pm 0.5$ & $-40.9 \pm 0.5$ \\
\hline PVS3 modified & $-93.9 \pm 0.5^{*}$ & - & - \\
\hline 80\% PVS3 modified & $-105.0 \pm 0.5$ & $-56.2 \pm 0.5$ & $-40.8 \pm 0.5$ \\
\hline PVS4 & $-111.5 \pm 0.5$ & $-64.0 \pm 0.5^{*}$ & $-50.5 \pm 0.5$ \\
\hline 80\% PVS4 & $-117.4 \pm 0.5$ & $-103.0 \pm 0.5$ & $-43.9 \pm 0.5$ \\
\hline PVSN & $-110.0 \pm 0.5$ & $-70.9 \pm 0.5$ & $-50.0 \pm 0.5$ \\
\hline 80\% PVSN & $-117.2 \pm 0.5$ & $-107.9 \pm 0.5$ & $-37.9 \pm 0.5$ \\
\hline
\end{tabular}

* - statistically significant difference relative to other PVS; ${ }^{*}$ - statistically significant difference relative to PVSN $(p=0.05), n=4$. 
only one heat capacity jump at temperature $T_{g}$ associated with a reverse glass transition process (transition from the solid amorphous state to the state of supercooled liquid). Neither exo- nor endothermic peaks were recorded, indicating no crystallization, at the cooling and warming stage. This fact testifies that at the cooling stage, PVS1 modified, PVS2, and PVS3 modified are completely transformed into the glassy state with a highly stable amorphous phase, which does not crystallize even under slow warming above the glass transition temperature.

In the thermograms of PVS4 and PVSN, in addition to the glass transition, an exothermic crystallization from the amorphous state (devitrification) peak and an endothermic peak of melting were registered (Fig. 1, Table 2). A superposition of peaks is observed in the PVS4 thermogram: the melting $\left(T_{m}=-50.5^{\circ} \mathrm{C}\right)$ begins before complete crystallization $\left(T_{c}=-64.0^{\circ} \mathrm{C}\right)$. It should be noted that for PVS4 and PVSN, the area under crystallization and melting curves does not differ significantly (Fig. 2).
This indicates that crystallization occurs only at the warming stage. The fact that crystallization and melting enthalpies for PVSN are 2.8 times greater than for PVS4 is an evidence of larger crystalline phase formation during PVSN warming. Moreover, the temperature interval between reverse glass transition and crystallization of the liquid phase in the samples is significantly broader for PVS4 (Fig. 1 and Table 2). Thus, the differences between the glass transition and crystallization temperature of PVS4 and PVSN are $47.5^{\circ} \mathrm{C}$ and $39.1^{\circ} \mathrm{C}$, correspondingly. This result demonstrates higher stability of the amorphous phase of PVS4 compared to PVSN. Probably, replacement of other cryoprotective compounds with sucrose in PVSN (Vicenja et al., 2010) affects negatively the stability of the amorphous phase of the resulting PVSN.

It should be noted that crystallization in PVS4 and PVSN may be related to the low warming rates used for calorimetric assays. The crystallization will most probably be

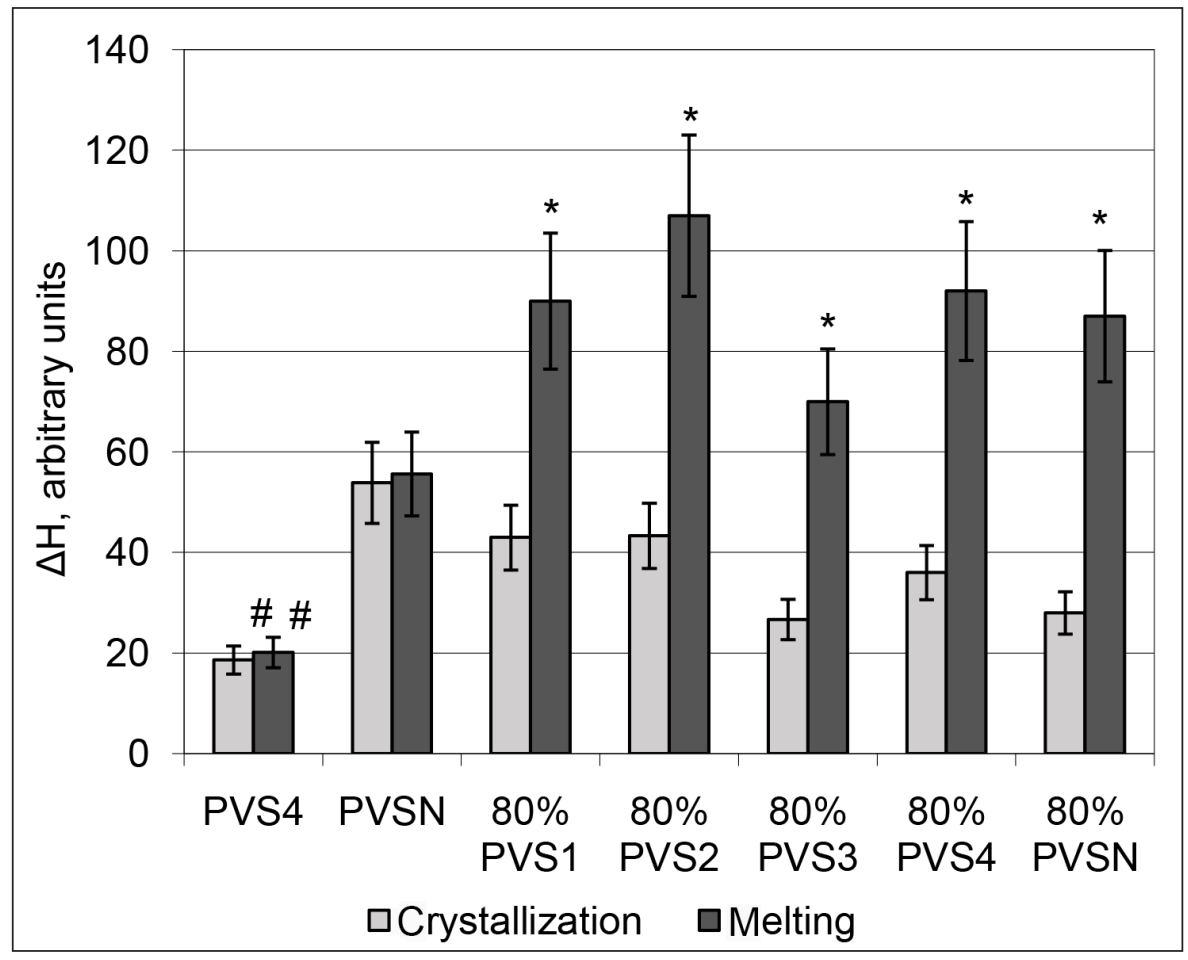

Fig. 2. Crystallization and melting enthalpy $(\Delta \mathrm{H})$ of PVSs; \# - statistically significant difference relative to other PVSs $(p=0.05),{ }^{*}$ - statistically significant difference relative to crystallization enthalpy of the same PVSs $(p=0.05), n=4$ 
avoided at higher warming rates. Previously, it has been reported that reducing the warming rate of PVS leads to an increased crystallization level, while glass transition is not significantly affected by the cooling or warming rate (Teixeira et al., 2014).

Analyzing the glass transition temperature and heat capacity of the studied PVSs, we revealed no significant differences in the glass transition temperatures for PVS2, PVS4, and PVSN, while this parameter was significantly higher for PVS3 modified (Fig. 2 and Table 2). This may be either due to the absence of DMSO and EG, which have low glass transition temperatures, or higher sucrose concentration in PVS3 modified.

Saturation of such large objects as shoot tips or dormant buds with $100 \%$ PVSs is rather a difficult task. To ensure effective saturation of the plant genetic resources with cryoprotectant, long time incubation is required. However, due to toxicity of PVSs, the cells on the sample surface may be damaged. It has been found that in some cases $80 \%$ concentration of PVS is sufficient for successful plant vitrification (Nishizawa et al., 1993). Therefore, the stability of the amorphous phase in $80 \%$ PVSs was also investigated in this research. As Table 2 shows, crystallization occurs in all $80 \%$ solutions of PVSs under slow warming. But the crystallization temperature differs for all the studied solutions. The amorphous phase stability was the highest for $80 \%$ PVS1 modified and for $80 \%$ PVS3 modified. In these solutions, the amorphous phase crystallization does not occur immediately after the appearance of the liquid phase, but at higher temperatures that are closer to the melting point. Crystallization of 80\% PVS1 modified and 80\% PVS3 modified can be prevented by changing the sample volume and the warming rate. Melting enthalpy for all the studied $80 \%$ PVSs was significantly higher than crystallization enthalpy (Fig. 2). We assume that the liquid in PVSs was partly crystallized at the cooling stage.

Analyzing heat capacity jumps in $80 \%$ and $100 \%$ PVSs, it was demonstrated that the glassforming ability for PVS2, PVS3 modified, and PVS4 did not differ significantly (Fig. 3). For $80 \%$ PVS1 modified and $80 \%$ PVSN, heat capacity jumps were significantly lower than for the corresponding $100 \%$ PVSs. This may be due to lower concentration of cryoprotectant components in these solutions.

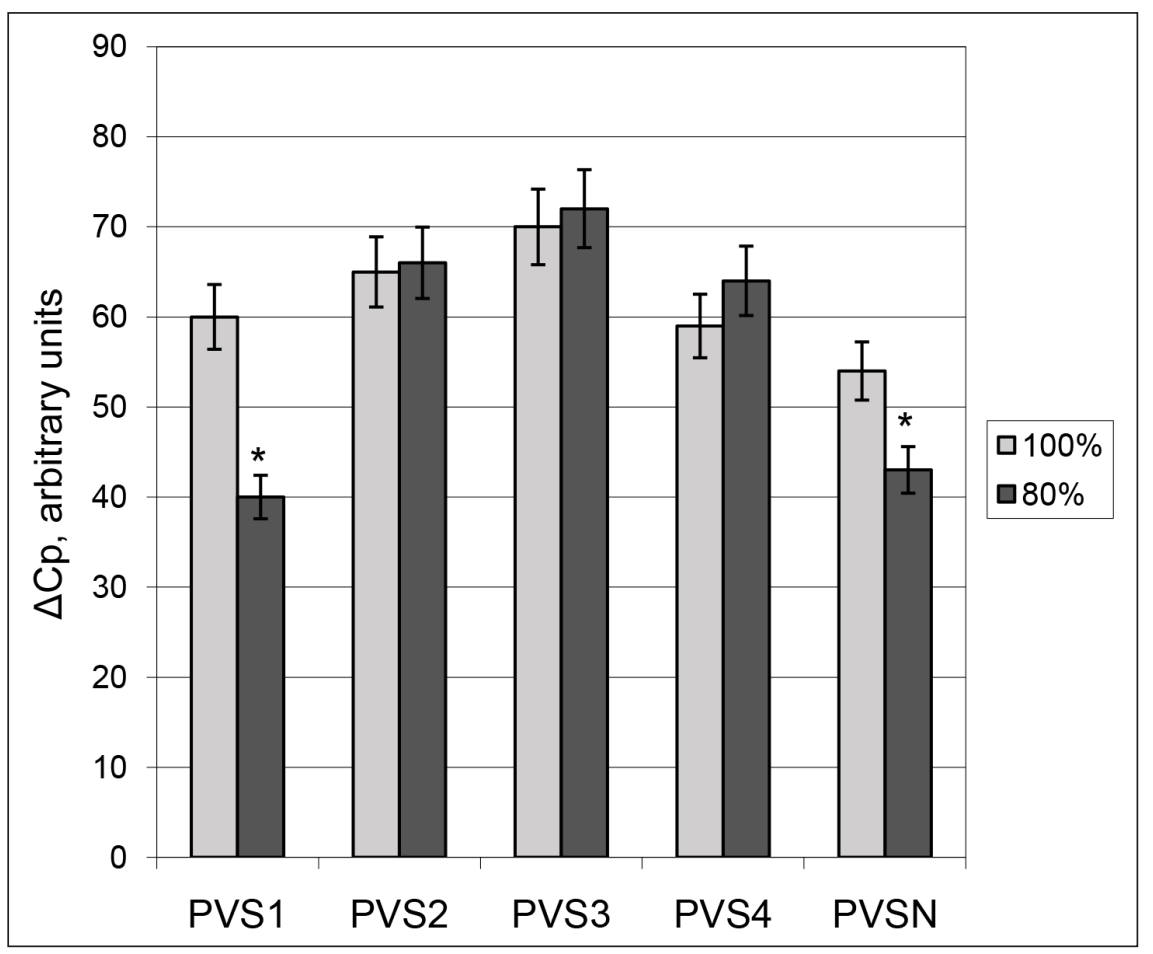

Fig. 3. Heat capacity jumps at the glass transition $(\Delta \mathrm{Cp}),{ }^{*}-$ statistically significant difference relative to $100 \%$ PVS $(p=0.05), n=4$ 


\section{CONCLUSIONS}

The higher glass-forming ability and amorphous state stability of PVS1 modified, PVS2, and PVS3 modified compared to PVS4 and PVSN suggest these cryoprotective media to be more promising during plant cryopreservation.

Received 26 June 2019 Accepted 11 December 2019

\section{References}

1. Baudot A, Alger L, Boutron P. Glass-Forming Tendency in the System Water-Dimethyl Sulfoxide. Cryobiology. 2000; 40(2): 151-8.

2. Baudot A, Boutron P. Glass-forming tendency and stability of aqueous solutions of diethylformamide and dimethylformamide. Cryobiology. 1998; 37(3): 187-99.

3. Baudot A, Peyridieu JF, Boutron P, Mazuer J, Odin J. Effect of saccharides on the glassforming tendency and stability of solutions of 2,3-butanediol, 1,2-propanediol, or 1,3-butanediol in water, phosphate-buffered saline, euro-collins solution, or saint thomas cardioplegic solution. Cryobiology. 1996; 33(3): 363-75.

4. Kim HH, Lee YG, Shin DJ, Ko HC, Gwag JG, Cho EG, Engelmann F. Development of alternative plant vitrification solutions in droplet vitrification procedures. Cryo Letters. 2009; 30(5): 320-34.

5. Nishizawa S, Sakai A, Amano Y, Matsuzawa T. Cryopreservation of asparagus (Asparagus officinalis L.) embryogenic suspension cells and subsequent plant regeneration by vitrification. Plant Sci. 1993; 91(1): 67-73.
6. Pritchard HW, Moat JF, Ferraz JBS, Marks TR, Camargo JLC, Nadarajan J, Ferraz IDK. Innovative approaches to the preservation of forest trees. Forest Ecol Manag. 2014; 333:88-98.

7. Ruzic D, Vujovic T, Cerovic R. Cryopreservation of cherry rootstock Gisela 5 (Prunus cerasus $\times$ Prunus canesces) shoot tips by droplet-vitrification technique. J Hortic Res. 2013; 21(2): 79-85.

8. Teixeira AS, Faltus M, Zamecnık J, GonzalezBenito ME, Molina-Garcia AD. Glass transition and heat capacity behaviors of plant vitrification solutions. Thermochim Acta. 2014; 593: 43-9.

9. Uragami A, Sakai A, Nagai M, Takahashi T. Survival of cultured cells and somatic embryos of Asparagus officinalis cryopreserved by vitrification. Plant Cell Rep. 1989; 8(7): 418-21.

10. Vicenja TI, Ivchenko TV, Stribul TF, Shevchenko NO. Kriozberigannja zrazkiv genofondu chasniku. Genetichni resursi roslin. 2010; 8: 200-208. Ukrainian.

11. Volis S. How to conserve threatened Chinese plant species with extremely small populations. Plant Divers. 2016; 38(1): 45-52.

12. Zámečník J, Faltus M, Bilavčík A, Kotková R. Comparison of cryopreservation methods of vegetatively propagated crops based on thermal analysis. Current Frontiers in Cryopreservation, Prof. Igor Katkov (Ed.), 2012, 333-58.

13. Zinchenko AV, Bobrova EN, Govorova YuS, Rozanova ED, Karpenko VG. Effect of low temperature storage of human placenta on phase transitions in fractions of placental extracts and in mixtures of the fractions with cells. Probl Cryobiol Cryomed. 2015; 25(2): 122-30. 
Krystyna Vozovyk, Olena Bobrova, Anton

Prystalov, Nadiya Shevchenko, Larisa Kuleshova

AUGALŲ VITRIFIKACIJOS TIRPALŲ AMORFINĖS BŪSENOS STABILUMAS

\section{Santrauka}

Norint gauti gyvybingus biologinius mėginius po kriokonservavimo vitrifikacijos metodu, yra svarbūs du veiksniai - krioprotektanto gebejimas virsti ledu aušinimo metu ir jo amorfinès būsenos stabilumas atšilimo metu. Šio darbo tikslas - ištirti augalų vitrifikacijos tirpalų (plant vitrification solutions, PVS) amorfinès būsenos stabilumą diferencinio nuskaitymo kalorimetrijos metodu. Tyrimo objektai buvo modifikuoti PVS1, PVS2, PVS3, PVS4 ir PVSN. Skystame azote užšaldytų tirpalų termogramos buvo užfiksuotos esant 0,5 laipsnio / min. atšilimo greičiui. PVS1, PVS2 ir PVS3 suledejimo temperatūra buvo atitinkamai $-109,0-115,3{ }^{\circ} \mathrm{C}$ ir $-93,9{ }^{\circ} \mathrm{C}$. Egzoterminių ir endoterminių pikų, patvirtinančių nesikristalizavimą tiek aušinimo, tiek atšilimo metu, neužregistruota. PVS4 ir PVSN termogramos, be suledejimo (atitinkamai $-111,5^{\circ} \mathrm{C}$ ir $-110,0^{\circ} \mathrm{C}$ ), rodè amorfinès būsenos (devitrifikacija) kristalizaciją ir ledo tirpimo smailes. PVSN kristalizacijos entalpija buvo 2,8 karto didesné, palyginti su PVS4. Atitinkamai PVSN kristalinè fazè taip pat buvo didesnè. Reikètų pažymèti, kad PVS4 ir PVSN kristalizacija gali būti susijusi su nedideliu atšilimo greičiu eksperimento metu. Esant didesniam atšilimo greičiui, šios kristalizacijos greičiausiai būtų galima išvengti. Taigi PVS1, PVS2 ir PVS3 pasižymi gebėjimu formuoti ledą ir stabilia amorfine būsena. PVS4 ir PVSN amorfinès būsenos stabilumas yra kur kas mažesnis, palyginti su PVS1, PVS2 ir PVS3.

Raktažodžiai: augalų vitrifikacijos tirpalai, suledèjimas, amorfinès būsenos stabilumas, devitrifikacija, ledo tirpimas 